\title{
Palynomorphs Dispersal of Plantago Type, in Elbasani Town - Albania
}

\author{
Dr. Admir Jançe ${ }^{1,3}$ \\ Prof. Dr. Gëzim Kapidani2 \\ MSc. Anila Jançe ${ }^{3}$ \\ Prof. As. Dr. Blerina Pupuleku \\ Prof. As. Dr. Nikoleta Kallajxhiu ${ }^{3}$ \\ Dr. Anxhela Dauti ${ }^{3}$ \\ 1 "Albanian University", Tiranë, Albania \\ 2 Tirana University, Albania \\ 3 "Aleksander Xhuvani" University, Albania \\ Email: adi_jance@yahoo.it
}

Doi:10.5901/ajis.2016.v5n3s1p20

\section{Abstract}

Paleopalynological data reported in this research, are received from underground layers that belongs to the geological period of New Holocene, in five different places belonging to the city of Elbasan. This research gives us certain paleopalynological input for the palynomorphs spreading to Plantago Type during New Holocene period. A significant number of environmental studies are done in Elbasan city during last thirty years. The goal where our paper is based, deals with the presentation of relationship amongst profoundness and distribution for the Plantago Type palynomorphs at various time intervals. The samples were received $25 \mathrm{~cm}$ depth from the surface to the $4 \mathrm{~m}$ of deepness, through a dry drilling sonde. Palynological input about this Type there were from any similar palynological research before, as from domestic and outside authors. Monitoring, numbering and microscopic photographing of palynomorphs is completed with Motic microscope BA310. Sample treatment also microscopic examinations were performed at "La Sapienza", University Rome. See from our perspective, some essential data were found, showing exactly the relationship amongst profoundness and quantitative presence of pollen to Plantago Type.

Keywords: Paleopalynological, New Holocene, palynomorphs, pollen, Plantago Type.

\section{Introduction}

Paleopalynology is the discipline that deals with the study of microscopic fossils made of organic materials resistant. This science was initially known as "Pollen Analysis" with the purpose the study of pollen grains and spores including fossils of the Quaternary period to paleoflora rebuild (Von Post, 1916). Comparison of herbal spores and pollen present in those primitive, allows us judging the performance of primitive and specialized features of outer wall of the grains (Pacini \& Franchi, 1978; Pacini \& Hesse, 2005).

The presented material gives palynological data of New Holocene deposits in Elbasani town. Palynology is focused on the study of finding the factors of vegetation change and human impact on the surrounding environment (Moore \& Webb, 1978).

Plant microfossils of this type are not analyzed earlier in the Elbasani Region as well as no kind of studies by foreign or native researcher on palynomorphs of this plant in underground layers belonging the geological period of New Holocene in Elbasani town. Palynological studies in our country in recent years have built and created an organized and collaborative group already in various disciplines (Jance \& Kapidani, 2011).

Through these kinds of researches are constructed a palynomorphs diagrams, reconstructed flora, vegetation, plant landscape and gives data on the natural history, ecological and climatic origin of the region under study (Forest et al., 1999; Davis, 1999).

The research in underground layers belonging the two thousand-year geological period ensure important information and tries to shed light on possible changes to the vegetation in this area, as well as the factors that have 
contributed to these changes over the years (Shalla, 1983; Muhameti et al., 1984).

Monitoring, numbering and microscopic photographing of palynomorphs is completed with Motic microscope BA310, with overstatement 1500x. Information on the manner of taking samples as well as final preparation mode in laboratory to the palynomorphs ready for preview of this plant is presented below in this paper. (Kapidani, 1996; Kapidani \& Jançe, 2004).

Paleopalynological data help in the discovery of traces of history on the use and cultivation of plants, feeding mode and the origin of agriculture (Bryant \& Holloway, 1996). The pollen quantifiable presence of Plantago Type in underground layers reveals the manner of distribution over the years about Plantago Type.

\section{Material and Methods}

Physical-chemical composition of the spores allows palynomorphs well saved and easily extracted from soil sediments. Basically all the extraction ways, join in principle methods of physical and chemical processing of $1 \mathrm{~cm}^{3}$ sediment (Faegri \& Iversen, 1989). The relief in all stationing where drilling is done has been flat, sub horizontal, small-angle slope on their way to the southern part of the city. Samples were taken every $25 \mathrm{~cm}$ depth from the surface to the depth reaching $4 \mathrm{~m}$. A total of 105 samples are taken and analyzed.

\subsection{The method of processing with hydrofluoric acid}

To prepare the palynomorphs for microscopic study of a sample, the material initially is treated only with $\mathrm{HCl}$ and then with concentrated HF (Wood et al., 1996; Green 2001). This method consists in the processing of $1 \mathrm{~cm}^{3}$ sediment with 10 $\mathrm{ml} \mathrm{HCl} 37 \%$, leaving together for a time of $15-20$ minutes.

Then the material is mixed with $6 \mathrm{ml}$ of $40 \% \mathrm{HF}$, leaving together for a period of 24 hours. Material rinsed with distilled water and is centrifuged for six minutes with 3,500 rotations per minute. Once obtained neutral environment, the precipitate is mixed with glycerol.

To avoid any difficulty in the microscope preparation, the glycerin is mixed with magnesium oxide MgO in a 5:1 ratio and it is ready to be observed in optical microscope (Moore \& Webb, 1978; Davis, 1999).

\subsection{Evaluation of processing methods.}

For chemical treatment of samples, there are many processing methods. We practiced all the possible methods. For our conditions more appropriate methods for the chemical treatment of the samples results that of processing with hydrofluoric acid (2.1). It is worth noting that, for the closure of preparations the gelatin method was used (Kisser, 1935).

\section{Analysis Results and Arguments}

If we look at table 1, we will find the quantitative data for the pollen presence of Plantago type, representative to the family of Plantaginaceae distributed by their presence in a defined deepness as well as the total spores' quantity for Plantago Type.

Table 1. The presence of palynomorphs by deepness

\begin{tabular}{||c|c|c||}
\hline \hline Specimen & Deepness (centimeters) & $\begin{array}{c}\text { Palynomorphs presence } \\
\text { (Plantago Typ - Plantaginaceae) }\end{array}$ \\
\hline 16 & 25 & 98 \\
\hline 15 & 50 & 96 \\
\hline 14 & 75 & 93 \\
\hline 13 & 100 & 83 \\
\hline 12 & 125 & 85 \\
\hline 11 & 150 & 82 \\
\hline 10 & 175 & 74 \\
\hline 9 & 200 & 84 \\
\hline 8 & 225 & 68 \\
\hline 7 & 250 & 60 \\
\hline
\end{tabular}




\begin{tabular}{||c|c|c||}
\hline 6 & 275 & 63 \\
\hline 5 & 300 & 61 \\
\hline 4 & 325 & 53 \\
\hline 3 & 350 & 55 \\
\hline 2 & 375 & 42 \\
\hline 1 & 400 & 36 \\
\hline \multicolumn{2}{|l|}{ General presence of palynomorphs } & 1133 \\
\hline
\end{tabular}

The minimum number (36 palynomorphs) is provided exactly in $400 \mathrm{~cm}$ of deepness meantime the greater presence of palynomorphs of Plantago Type that is 98 , is battling close to surface exactly in the $25 \mathrm{~cm}$ of deepness.

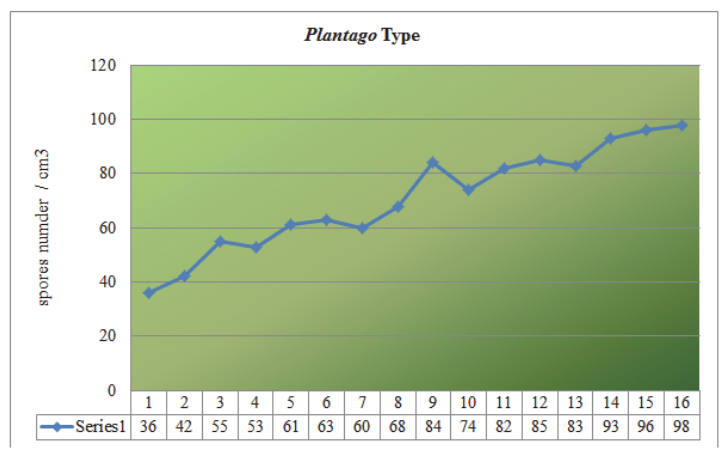

Figure 1. The palynomorphs distribution of Plantago Type by deepness

If observe figure 1 we see distinctly a significant increment to the palynomorphs of Plantago Type, part of Plantaginaceae family (Photos 1) from the profoundness to the superficies.

Observing the quantitative information, which we are given in the above table the palynomorphs aggregate number of Plantago Type, we find a fairly significant presence of 1133 spores.

By a thorough monitoring of the Table 1, gives us the right to say that: The presence of Plantago Type palynomorphs are observed at all deepness. As well if we observe carefully the Figure 1 , it is clearly noted that: The Plantago Type palynomorphs have a significant augmentation of the attendance from the profoundness to the terrestrial area. The representatives of this plant usually grown in compressed and stable ground, so repeatedly this plant occurs along the paths, through rocks or in crevices of pavements. This plant, also rarely occurs along the edge of the driveway.

The leading cause for this presence of Plantago Type palynomorphs maybe should be connected with the mandatory requirement to this plant for human beings. We found enough material to contemporary literature that proves the use as herbal medicines of Plantago varieties, very long time ago. Plantago varieties as a medicinal plant and daily use find a spread as: disinfectant, against the swellings, treacle, anti-allergic, diuretic, soothing pain, tanner, contractile and cough suppressant. (Samuelsen, 2000).

In the traditional beliefs thought that this herb is capable for the treating and healing of the poisonous snake nip. Also among this plant has found a use as nutrition of ancient humanity. Decoct boiled or salt-glaze derived from this plant also find use for the treatment of various problems coming from the streets of the respiratory system.

Upward curve or the addition of Plantago Type palynomorphs towards the ground surface can be explained on the grounds that the palynomorphs of the surface can be well maintained than those exclusively deep, not avoid the impact of weather and environmental elements.

The quantitative data through spores and pollens variety of Plantago type shows the direction of evolution of this family mentioned in the study.

The palynomorphs amount of Plantago Type in subterranean strata reveals the spreading way throughout a long time about Plantago Type, part of Plantaginaceae Family. 


\section{Outcomes}

1. The Plantago type palynomorphs have a meaningful growth from the profoundness to the ground superficies.

2. The Plantago type palynomorphs are found in every sample and at all depths.

3. We believe that the rate of growth of particles pollen of Plantago Type in all of these samples, in addition to the impact of ecological factors in maintaining good, must be related to the influence of anthropogenic factors in the necessity of presence of plants needed to.

\section{References}

Bryant, V.M., \& Holloway, R.G. (1996). Archaeological palynology, in Palynology: Principles and Applications, vol. 3 (J. Jansonius and D. C. McGregor, Eds.) Dallas, Am. Assoc. Strat. Palynol. Found, 913-917.

Davis, O.K. (1999). Preliminary pollen analysis of Neogene and Quaternary sediment of The Great Salt Lake, U.S.A. - Proceedings Pliocene Conference, AASP Contribution, Arizona, 34: 227-240.

Faegri, K., \& Iversen, J. (1989). Textbook of Pollen Analysis, 4th Edition. Chichester, 328 pp.

Forest, C.E. (1999). Paleoaltimetry incorporating atmospheric physics and botanical estimates of paleoclimate. - Bulletin of the Geological Society of America, 111: 497-511.

Green O.R. (2001). A manual of practical laboratory and field techniques in palaeobiology. Dordrecht, Kluwer Academic Publishers: 538 pp.

Jançe, A., \& Kapidani, G. (2011). Palynological data of Compositae and Umbelliferae families during Holocene Period in Elbasan city J. Int. Environmental Application and Science, (JIEAS - 2011), Vol. 6, No. 5: 729-733.

Kapidani, G. (1996). Bazat e Palinologjisë. - Sejko Infoservis, Elbasan, 230 pp.

Kapidani, G. (2005). Fjalori i Terminologjisë Palinologjike. - Sejko, Elbasan, 149 pp.

Kapidani, G., \& Jançe, A. (2004). Të dhëna të pjesshme mbi studimin e sporeve dhe poleneve në depozitimet e Kuaternarit në qytetin e Elbasanit. - Buletini Shkencor UE, Elbasan, 1: 58-65.

Kisser, J. (1935). Bemerkungen zum Einschluss in Glycerin-Gelatine. Z. wiss. Mikr. Berlin, 51 pp.

Moore, P.D., \& Webb, J.A. (1978). An illustrated Guide to Pollen Analysis. - Department of Plant Sciences, King's College, Hodder and Stoughton, London, 133: 216-217.

Muhameti, P., Gjani, E., \& Roqi, R. (1984). Palinostratigrafia e depozitimeve të Tortonianit në pjesën lindore të Ultësirës pranë Adriatikut në bazë të studimit të sporopoleninit. - Buletini Nafta dhe Gazi, Fier, 204 pp.

Pacini, E., \& Franchi, G.G. (1978). II polline: Biologia e Aplicazioni. - Quaderni di biologia, Bologna, 12: 8-53.

Paccini, E., \& Hesse, M. (2005). Pollenkitt- its composition forms and functions. Flora, 200: 399-415.

Samuelsen, A. B. (2000). The traditional uses, chemical constituents and biological activities of Plantago major L. A review. Journal of Ethnopharmacology, 77 pp. (1-2): 1. doi:10.1016/S0378-8741(00)00212-9. ISSN 0378-8741.

Shalla, M., Xhomo, A., Kodra, A., \& Xhafa, Z. (1983). Gjeologjia e Shqipërisë. Shtëpia Botuese "Naim Frashëri", Tiranë, 343 pp.

Von Post L. (1916). Om skogsträdpollen i sydsvenska torfmosselagerföljder (foredragsreferat). Geologiska Föreningens i Stockholm Förhandlingar, 38: 384-390.

Wood G.D., Gabriel A.M., \& Lawson J.C. (1996). Palynological techniques - processing and microscopy. In: Jansonius J. \& McGregor D.C. (eds.): Palynology: principles and applications, American Association of Stratigraphic Palynologists Found., 1: 29-50.

Supplement 1. Microscopic photographs.

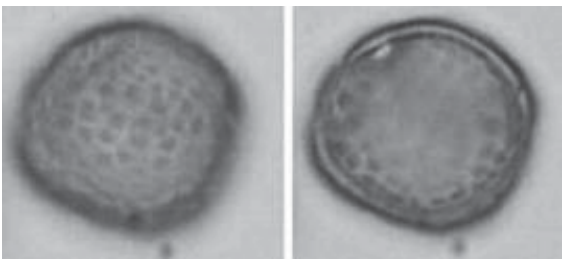

Ph. 1. Plantago Type pollens 